\title{
12 Cognitive science of religion and the nature of the divine
}

\author{
A pluralist, nonconfessional \\ approach
}

Johan De Smedt and Helen De Cruz

\section{Introduction}

Cognitive science of religion (CSR) indicates that people naturally veer toward beliefs that are quite divergent from Anselmian monotheism or Christian theism. Some authors (e.g., Shook 2017) have taken this view as a starting point for a debunking argument against religion, whereas others (e.g., Barrett 2009) have tried to vindicate Christian theism by appealing to the noetic effects of sin, or the Fall.

In this chapter, we use a different approach: we ask what theologians can learn from CSR about the nature of the divine by looking at the CSR literature and what it identifies as commonalities across religions. We use a pluralist, nonconfessional approach to outline properties of the divine with reference to the CSR literature. We connect our approach to Hick's religious pluralism, Ramakrishna's realization of God through multiple spiritual paths, and Gellman's inexhaustible plenitude.

\section{The origins of religious beliefs and their justification}

What can the origins of religious beliefs tell us about their justification? From the eighteenth century onward, philosophers and scientists have considered this question by outlining natural histories of religion. These accounts not only examine the origins of religious beliefs but also ask whether those beliefs could be rationally maintained in light of their origins. Typically, eighteenth-century natural histories of religion (e.g., De Fontenelle 1728; Hume 1757) emphasized the diversity of religious beliefs and expressed skepticism about their rationality. For example, Hume $(1757,2)$ stated that religious beliefs were so diverse that "no two nations, and scarce any two men, have ever agreed precisely in the same sentiments."

By contrast, other authors since the early modern period, such as John Calvin and Pierre Gassendi, emphasized the universality of religion and took this as a starting point for the truth of religious claims. For example, Calvin (1559/1960, 43-46), following Cicero, made the empirical claim that there is "no nation so barbarous, no people so savage, that they have 
not a deep-seated conviction that there is a God" and concluded "it is not a doctrine that must be first learned in school, but one of which each of us is master from his mother's womb and which nature itself permits no one to forget." Calvin appealed to an innate sense of the divine, a sensus divinitatis, which instills religious beliefs in us. An influential updated version of this argument is Plantinga's (2000) extended Aquinas/Calvin model, which argues that Christian belief can have warrant, even in the absence of rational argument, because it is produced by a properly working sensus divinitatis that God implanted in us.

However, religious diversity threatens to undermine any straightforward claim from universality to truth. If religious belief is universal, why do people across religious traditions hold mutually incompatible religious beliefs? The Medieval Muslim theologian Al-Ghazālī worried about this question, as he mused that children of Muslims tend to turn out Muslims, children of Jews tend to grow up as Jews, and children of Christians tend to become Christians. He proposed that everyone is born with the fitrah, a basic moral sense and natural belief in God, which can give rise to authentic religion or be perverted into false religions: "Every infant is born endowed with the fitrah: then his parents make him Jew or Christian or Magian [Zoroastrian]" (Al-Ghazālī, 1100/2006, 19-20). In this way, cultural influences can either help properly cultivate certain religious beliefs or have a distorting influence and give rise to false (in Al-Ghazālī's view, non-Muslim) ones. Similarly, Christian authors such as Calvin (1559/1960) and, more recently, Plantinga $(2000,184)$ appeal to the Fall as an explanation for why people's "natural knowledge of God has been compromised, weakened, reduced, smothered, overlaid, or impeded." As a result of our sinful condition, we are not only damaged in our cognitive structures, which hampers our knowledge of God, but also in our affection, which fails to orient itself to God.

Any argument that takes the prevalence of religious beliefs as a starting point to make claims about the existence and nature of the divine stumbles on the problem of religious diversity. In order to address this problem, authors from monotheistic traditions appeal to a sense of the divine combined with auxiliary principles such as the noetic effects of $\sin$ (Calvin and Plantinga) or to cultural transmission (Al-Ghazālī) to explain why religious beliefs are so divergent. For these authors, religious diversity is a problem. But, as we will show later, religious pluralism celebrates the diversity of religious beliefs, while at the same allowing for something akin to a sense of the divine.

\section{The cognitive science of religion}

CSR can shed new light on why religious beliefs are widespread and diverse. CSR is an interdisciplinary research program that uses findings from, among others, developmental psychology, cognitive science, and anthropology. A unifying theme throughout this literature is the commitment of 
CSR authors to the idea that religion is natural. This does not necessarily mean religious beliefs are innate (although a few authors, e.g., Bering (2011) have made this stronger claim), but that such beliefs come relatively easily, with little formal instruction, as part of ordinary human development and socialization (McCauley 2011). CSR also holds that religious beliefs are the result of several cognitive processes, which are not exceptional but operate in everyday life, such as discerning teleology, detecting agency, and thinking about other people's minds. Within different cultures, these cognitive building blocks give rise to a wide range of religious beliefs. We will here briefly review three lines of research in CSR scholarship: belief in supernatural agents and its connection to cooperation, teleological thinking, and afterlife beliefs.

Across cultures, people believe in a variety of supernatural agents that are concerned with moral or ritual violations. Such agents include powerful gods such as Zeus or Kālī, the Hindu goddess who destroys evil, bestows liberation, and protects her people. But they also include supernatural agents with more limited capacities, such as the ancestors, place spirits, and the Chinese Kitchen God, who reports to the Jade Emperor about how families behaved during the past year. There is increasing evidence that belief in such supernatural agents enhances cooperation among members of the same religion by providing a sense of social control: people are less likely to behave antisocially (e.g., steal, cheat) if they believe they are being watched. Social control is particularly effective if the agents who are watching have the capacity to punish transgressions.

Initially, CSR authors believed that only very powerful creator gods, termed high gods, could foster cooperation in this way, because only high gods would care about moral transgressions. For example, Norenzayan (2013) speculates that belief in high gods decreased antisocial behavior, thereby enabling people to live in larger groups. However, more recently, there is increasing evidence that belief in a broader range of supernatural agents can motivate people to cooperate. For example, Purzycki et al. (2016) investigated whether people who believe in supernatural agents would be more generous toward others who have the same religion as themselves but who live far away. They let participants of a variety of supernatural faiths, including belief in garden spirits (horticulturalists from Tanna, Vanuatu), ancestor spirits (Yasawa, Fiji), and spirit masters, local spirits who have dominion over a small part of the landscape (Tyva, Siberia), play a game where they could allocate money either to themselves or to a distant or close person with the same religion. People were more generous to distant co-religionists if the supernatural beings they believed in were more knowledgeable and more able to punish moral transgressions. This supports broad supernatural punishment theory, which holds that a wide range of supernatural beings, not just supreme creators, can instill cooperation (Watts et al. 2015).

Cultural evolution, or potentially gene-culture co-evolution, is hypothesized as the driving factor in the cultural spread of the belief in specific 
supernatural beings. If belief in supernatural agents who are morally concerned and able to punish ritual or moral transgressions increases cooperation among people who hold the same beliefs, we can predict that such beliefs confer a fitness advantage (Norenzayan and Shariff 2008). In groups where belief in supernatural punishment by gods, spirits, or other supernatural beings is common, one could thus expect higher degrees of cooperation. This would provide selective pressure at a cultural level for the maintenance and spread of belief in supernatural punishment, and perhaps also help foster biological adaptations that make us prone to believing in such agents (Bering and Johnson 2005).

Teleological thinking is intimately tied to religion across cultures. Children and adults prefer teleological explanations for the origin of natural beings, including biological and nonbiological natural kinds, such as giraffes, tiger paws, and mountains. In a typical experiment, participants are offered the choice between two kinds of explanation for why a given object exists. Does it rain so that animals and plants can drink (a teleological explanation) or because water condenses into droplets (a mechanistic explanation)? There is robust empirical evidence that young children up to the age of ten prefer teleological over mechanistic explanations (Kelemen 1999). Moreover, when adults are put under time pressure, they are also more likely to endorse false teleological explanations, for example, "the Sun radiates heat because warmth nurtures life" (Kelemen and Rosset 2009). $\mathrm{PhD}$ holders in the sciences and humanities are also liable to endorse false teleological explanations under time pressure, albeit to a lesser extent than the general population (Kelemen, Rottman, and Seston 2013).

There is a link between teleological thinking and religiosity. Kelemen (2004) initially argued that children are intuitive theists because they attribute teleological features of the world to an intelligent designer. But later experiments cast doubt on this interpretation and indicate a broader connection between teleological thinking and supernatural beliefs and practices. For example, Kelemen, Rottman, and Seston (2013) found that scientists who tend to think of the Earth as having agency and caring for creatures (so-called Gaia beliefs), as well as theist scientists, think more teleologically than scientists who don't believe in the Earth as an agent or in God. Similarly, ordinary adults from the United States and Finland who endorse either Gaia beliefs or classical theist beliefs are more likely to think that objects (e.g., a maple leaf, a mountain) were made purposively by some being (Järnefelt, Canfield, and Kelemen 2015). Järnefelt et al. (2019) studied teleological beliefs in China, in a group of participants who mostly self-identify as atheists. However, all participants engaged at least in some religious practices, including revering ancestors, feng shui, and using lucky charms. They found that the more participants engaged in such religious practices, the more likely they were to endorse teleological explanations for nonbiological natural kinds. The Finnish and Chinese studies tentatively suggest that teleological thinking might also lie at the basis of nontheistic religious beliefs 
and practices. Indeed, research on teleology and life events suggests that teleological thinking persists in atheists and agnostics (e.g., Heywood and Bering 2014): when spontaneously reflecting on significant life events, atheists offer fewer teleological explanations than theists, but still suggest that things happen to them for a reason, for example, claiming that the universe wanted to give them a sign or send them a message.

CSR has also shown that afterlife beliefs are robust and cross-culturally widespread. Belief in the afterlife probably is rooted in social thinking, in our ordinary attributions of mental states to other agents in everyday life. As Merleau-Ponty $(1945 / 2002,250)$ already suggested, it is hard to imagine ourselves as no longer existing - it becomes intuitive and plausible to imagine ourselves in an afterlife, and any cultural scripts that propose an afterlife (e.g., reincarnation) can easily spread. Moreover, we find it difficult to imagine that others, especially those we interact with frequently, no longer exist. We continue to attribute mental states to them, even if they are not in physical proximity or if they are dead. Bloom (2004) characterizes humans as intuitive dualists: young children already make an intuitive distinction between people, using intuitive psychology to reason about them, and physical objects, using intuitive physics to interact with them. However, Hodge (2011) argues that our thinking about dead agents is not easily captured in mind/body dualistic terms. Watson-Jones et al. (2017) found that Christians in the United States think our psychology (personality, preferences, desires) will survive after death, but not necessarily our bodies, whereas Christians from Vanuatu (Melanesia) believe that our biological properties (bodies and bodily functions) will survive into the afterlife, but not necessarily our psychology. This indicates that within cultures and even within the same religion, different belief scripts about postmortem survival may develop and that Bloom's (2004) intuitive dualism may be too simplistic.

\section{What does CSR mean for knowledge of the divine?}

CSR shows that religious beliefs are the result of universal cognitive dispositions. Because these dispositions are underdetermined, religious diversity becomes inevitable. As we have seen, humans are naturally inclined to believe in supernatural agents, but these are not necessarily monotheistic gods. We are inclined to ascribe teleology, but this is linked to a broad notion of supernatural agency, including Mother Earth and ancestral spirits. We tend to believe in an afterlife, but that afterlife takes a number of different forms.

What, if any, conclusions about our knowledge of the divine can we draw from CSR? Shook (2017) takes CSR to claim that religious beliefs are innate, a position most CSR authors do not endorse (but see Bering 2011), and then subsequently takes the diversity of religious beliefs to spell bad news for their justification. Teehan (2016) argues that CSR puts pressure on theological views, such as that God would be omnibenevolent: religions 
encourage in-group favoritism and out-group derogation, which would entail that social evils such as racism and xenophobia would be part of God's plan. This would lower our belief that an omnibenevolent God exists, and theodicies that appeal to the Fall do not solve this problem.

By contrast, Barrett (2009) appeals to the Fall and sinfulness to explain religious diversity. If the cognitive dispositions we discussed earlier are God's way of instilling religious beliefs, why would they allow so much diversity?

One possible answer is that a perfectly adequate concept of God does come as part of our biological heritage but that living in a sinful, fallen world this concept grows corrupt as we grow. If not for broken relationships, corrupt social structures, flawed religious communities, and the suffering that people inflict upon each other, perhaps children would inevitably form a perfectly acceptable concept of God. The diversity in god concepts we see is a consequence of human error and not divine design.

(Barrett 2009, 97-98)

This approach, like Calvin's and Plantinga's appeal to the noetic effects of sin, comes at a cost: on the one hand, there is an inference from religious belief to the truth of those beliefs, but on the other hand, any religious beliefs that do not fit the preconceptions of these authors are dismissed as results of defective cognition. How can Barrett be sure what a "perfectly acceptable concept of God" is, and how can he prevent those human errors from bleeding out and casting doubt on all religious beliefs? This is a problem he does not address.

We want to suggest an alternative approach: the dispositions outlined by CSR do give us some insight into the divine, and religious diversity is not the result of sinfulness or error. Such a proposal fits within religious pluralism, the view that different religious beliefs provide knowledge (of some sort) of God or a supernatural reality. Religious pluralism has been defended by authors from different religious traditions, for example, the Christian John Hick (2006), the Hindu Sri Ramakrishna (Maharaj 2017), and the Jew Jerome Gellman (1997). A common starting point for proponents of religious pluralism is the parable of the blind men and the elephant, according to which several blind men approach the pachyderm. One feels the trunk and concludes an elephant is long and soft, another feels the tusks and concludes it is smooth and hard, yet another a leg and surmises it is broad and firm. Each blind man captures something of the reality of the elephant, but it would be a mistake for each to assume that their testimony is the best description of the animal and to ignore the contradictions in the others' depictions. Each blind man mistakes a part for the whole - rashly assuming his knowledge of the elephant is the only and whole truth about it. In the parable, it does not seem to occur to the blind men to talk to one another or to move around the elephant to feel its other body parts in order to gain 
a fuller understanding. Likewise, in real life adherents to different religions rarely take each other's views of the supernatural into consideration. Proponents of pluralism have provided divergent ways to flesh out how we come to knowledge of supernatural reality.

Hick (2006) postulates an ultimate reality that is conceived of in different ways within various cultural traditions. This ultimate reality is real (not a mere cultural construct), and religious practices and mystical perception grasp something genuine about it. At the same time, Hick avers that the supernatural remains ultimately unknowable. This Kantian perspective draws a distinction between a noumenal transcendent reality and the objects of devotion and religious practices that are mere phenomenal manifestations that believers construct. Hick's pluralism is not analogous to the situation of the blind men and the elephant: the elephant is not an unknowable noumenon, as much about the elephant is known by the individual blind men. In the light of CSR, Hick's account is unsatisfying, as it does not explain the common threads across religious traditions, such as belief in supernatural agents who care about what we do, belief that things occur for a reason, and belief in an afterlife. These commonalities would have to be dismissed because ultimate reality is unknowable. In Hick's Kantian picture, it does not matter whether religious beliefs are convergent to some extent (as CSR suggests) or diverge without clear bounds, as they grasp at an unknowable transcendent reality.

Ramakrishna was a Bengali Hindu mystic, originally a priest of the goddess Kālī (see Maharaj 2017 for a comprehensive overview). After researching and mystically engaging with a host of other traditions, he advocated the position that all religions are spiritual paths to the same divine reality, which he called God. To explain apparent tensions between religions - for example, that some see God as impersonal and others as personal, some see God as immanent, and others as transcendent, some see God as having some (anthropomorphic) form and others as formless - Ramakrishna argued that God is infinite and illimitable: God is both personal and impersonal, God is like a mother, but also like a father, a lover, a friend. Divergent paths of devotion lead to the same divine reality. As such, Ramakrishna's view aligns closer to the parable of the elephant and the blind men than does Hick's, as it accepts that different religious traditions capture aspects of divine reality. A similar concept is employed by Gellman (1997), who sees God as having an inexhaustible plenitude. God presents himself to mystics in different aspects, including his nonpersonal aspects to nontheistic mystics. There are some differences between Gellman's and Ramakrishna's proposals: Gellman offers this as a speculative hypothesis, rather than as an experienced state of affairs, and his account is focused on mystics rather than on religious believers more generally.

CSR does not privilege a specific religion, but indicates that there are common threads among religious traditions. This scientific claim is in line 
with Ramakrishna's pluralism. Why would God present himself in such varying ways? CSR indicates that religious beliefs arise as the result of an interaction between cultural context and ordinary cognitive processes. Because these cognitive processes allow for a wide range of religious beliefs, religious diversity becomes inevitable. At the same time, CSR also predicts robust cross-cultural similarities in religious beliefs and practices. Ramakrishna's views on religious diversity fit well with these predictions, as he saw different religions as multiple paths leading to the same supernatural reality. Contrary to Christian exclusivist thinkers, he saw religious diversity as a result of a deliberate divine plan, and not an unfortunate accident, because people from different religious communities have different cultural backgrounds, which make some religious views more palatable or plausible given their worldview. Ramakrishna used the parable of a mother who prepares several dishes to suit the different tastes of her children.

Suppose a mother has five children and a fish is bought for the family. She doesn't cook pilau or kalia for all of them. All have not the same power of digestion; so she prepares a simple stew for some. But she loves all her children equally [. . .] God has made different religions to suit different aspirants, times, and countries. All doctrines are so many paths; but a path is by no means God Himself. [. . .] Indeed, one can reach God if one follows any of the paths with whole-hearted devotion.

(Ramakrishna, cited in Maharaj 2017, 188)

\section{Concluding thoughts}

CSR shows that religions have substantial similarities. As we reviewed here, CSR indicates that people across cultures believe in supernatural agents who are concerned with what we do. They may be watchful garden spirits, or ancestors, or powerful gods, but they care about ritual and moral violations and thus discourage antisocial behavior. Moreover, those religious agents have goals: they make things happen or create natural kinds for some purpose or reason. Religious traditions suggest that humans will continue to exist in some form after death, in a distinctive afterlife as revered ancestors, souls in Heaven or Hell, or through reincarnation. This recurring set of beliefs accords better with Ramakrishna's religious pluralism that acknowledges such beliefs as different ways of tracking supernatural reality than with Hick's religious pluralism, which regards ultimate reality as unknowable. The findings of CSR do not allow one to infer which theological position is correct, but they can be put to use by empirically engaged theologians as they convey relevant information about the supernatural. This chapter provides initial groundwork for such an empirically informed natural theology. 


\section{References}

Al-Ghazālī. 1100/2006. Deliverance from Error, trans. Richard J. McCarthy. Louisville, KY: Fons Vitae.

Barrett, Justin L. 2009. "Cognitive Science, Religion, and Theology.” In The Believing Primate. Scientific, Philosophical, and Theological Reflections on the Origin of Religion, edited by Jeffrey Schloss and Michael J. Murray, 76-99. Oxford: Oxford University Press. doi:10.1093/mind/fzq080

Bering, Jesse M. 2011. The God Instinct. The Psychology of Souls, Destiny and the Meaning of Life. London: Nicholas Brealy. doi:10.24204/ejpr.v5i3.229

Bering, Jesse M., and Dominic Johnson. 2005. " 'O Lord You Perceive My Thoughts from Afar': Recursiveness and the Evolution of Supernatural Agency." Journal of Cognition and Culture 5 (1-2): 118-142. doi:10.1163/1568537054068679

Bloom, Paul. 2004. Descartes' Baby: How Child Development Explains What Makes Us Human. London: Arrow Books.

Calvin, John. 1559/1960. Institutes of the Christian Religion, trans. Ford Lewis Battles. Philadelphia: Westminster Press.

de Fontenelle, Bernard L.B. 1728. Histoire des Oracles. La Haye: Gosse \& Neaulme. Gellman, Jerome I. 1997. Experience of God and the Rationality of Theistic Belief. Ithaca, NY: Cornell University Press.

Heywood, Bethany T., and Jesse M. Bering. 2014. “'Meant to Be': How Religious Beliefs and Cultural Religiosity Affect the Implicit Bias to Think Teleologically.” Religion, Brain \& Behavior 4 (3): 183-201. doi:10.1080/2153599x.2013.782888

Hick, John. 2006. The New Frontier of Religion and Science: Religious Experience, Neuroscience and the Transcendent. Basingstoke: Palgrave Macmillan.

Hodge, Mitch K. 2011. "On Imagining the Afterlife." Journal of Cognition and Culture 11 (3): 367-389.

Hume, David. 1757. “The Natural History of Religion.” In Four Dissertations, 1-117. London: A Millar.

Järnefelt, Elisa, Caitlin F. Canfield, and Deborah Kelemen. 2015. "The Divided Mind of a Disbeliever: Intuitive Beliefs About Nature as Purposefully Created Among Different Groups of Non-Religious Adults." Cognition 140: 72-88. doi:10.1016/j.cognition.2015.02.005

Järnefelt, Elisa, Liqi Zhu, Caitlin F. Canfield, Marian Chen, and Deborah Kelemen. 2019. "Reasoning About Nature's Agency and Design in the Cultural Context of China." Religion, Brain \& Behavior 9 (2): 156-178. doi:10.1080/21535 99x.2018.1449137

Kelemen, Deborah. 1999. "Why Are Rocks Pointy? Children's Preference for Teleological Explanations of the Natural World." Developmental Psychology 35 (6): 1440-1452. doi:10.1037//0012-1649.35.6.1440

Kelemen, Deborah. 2004. “Are Children 'Intuitive Theists'? Reasoning About Purpose and Design in Nature." Psychological Science 15 (5): 295-301. doi:10.1111/j.0956-7976.2004.00672.x

Kelemen, Deborah, and Evelyn Rosset. 2009. “The Human Function Compunction: Teleological Explanation in Adults.” Cognition 111 (1): 138-143. doi:10.1016/j. cognition.2009.01.001

Kelemen, Deborah, Joshua Rottman, and Rebecca Seston. 2013. "Professional Physical Scientists Display Tenacious Teleological Tendencies: Purpose-Based Reasoning as a Cognitive Default." Journal of Experimental Psychology: General 142 (4): 1074-1083. doi:10.1037/a0030399 
Maharaj, Ayon. 2017. “ 'God Is Infinite, and the Paths to God Are Infinite': A Reconstruction and Defense of Sri Ramakrishna's Vijñāna-Based Model of Religious Pluralism." Journal of Religion 97 (2): 181-213. doi:10.1086/690478

McCauley, Robert N. 2011. Why Religion Is Natural and Science Is Not. Oxford: Oxford University Press.

Merleau-Ponty, Maurice. 1945/2002. Phenomenology of Perception, trans. Colin Smith. London \& New York: Routledge.

Norenzayan, Ara, and Azim Shariff. 2008. "The Origin and Evolution of Religious Prosociality.” Science 322 (5898): 58-62. doi:10.1126/science.1158757

Norenzayan, Ara. 2013. Big Gods. How Religion Transformed Cooperation and Conflict. Princeton, NJ: Princeton University Press. doi:10.1111/heyj.12678

Plantinga, Alvin. 2000. Warranted Christian Belief. New York: Oxford University Press.

Purzycki, Benjamin G., Coren Apicella, Quentin D. Atkinson, Emma Cohen, Rita A. McNamara, Aiyana K. Willard, et al. 2016. "Moralistic Gods, Supernatural Punishment and the Expansion of Human Sociality." Nature 530: 327-330. doi:10.1038/nature16980

Shook, John R. 2017. “Are People Born to Be Believers, or Are Gods Born to Be Believed?" Method of Theory in the Study of Religion 29 (4-5): 353-373. doi:10. 1163/15700682-12341389

Teehan, John. 2016. "Cognitive Science, Evil and God." In Advances in Religion, Cognitive Science, and Experimental Philosophy, edited by Helen De Cruz and Ryan Nichols. 39-60. London: Bloomsbury Academic. doi:10.1558/jcsr.36383

Watson-Jones, Rachel, Justin T. Busch, Paul L. Harris, and Cristine H. Legare. 2017. "Does the Body Survive Death? Cultural Variation in Beliefs About Life Everlasting." Cognitive Science 41: 455-476. doi:10.1111/cogs.12430

Watts, Joseph, Simon J. Greenhill, Quentin D. Atkinson, Thomas E. Currie, Joseph Bulbulia, and Russell D. Gray. 2015. "Broad Supernatural Punishment but Not Moralizing High Gods Precede the Evolution of Political Complexity in Austronesia." Proceedings of the Royal Society of London B: Biological Sciences 282 (1804): 20142556. doi:10.1098/rspb.2014.2556 